\title{
Leadership Structure, Corporate Reporting and Employee Performance in State Corporations: A Case Study of Kenya Bureau of Standards (KEBS)
}

\author{
Beatrice Chepkirui Lugadiru ${ }^{a}$, Brown Kitur ${ }^{b}$ \\ a Department of Business Administration, The Manageent University of Africa, \\ P Ob Box 29677-00100 Nairobi Kenya \\ ${ }^{b}$ Deaprtment of Business Administration, The Management University of Africa,
}

P.O Box 29677 -00100, Nairobi Kenya.

ablugadiru@gmail.com; bbkitur@mua.ac.ke

\begin{abstract}
The main objective was to examine the corporate governance practices and employee performance in state corporations, a case study of Kenya Bureau of Standards with specific objectives being; to examine the influence of leadership structure and corporate reporting on employee performance at Kenya Bureau of Standards. The study is guided and anchored on the following theoretical foundations; stakeholder theory, agency theory, and stewardship theory. The study's main anchor theory was stakeholder theory. Adescriptive research design was adopted for conducting the study that targets a population of 1000, and a sample size of 100 was selected using stratified random sampling. Data was collected using questionnaires. The quantitative data were analyzed using SPSS. The data was presented using tables and figures. Inferential statistics were used for showing how variables are related (regression and correlations). The study established that leadership structure, corporate reporting, and employee performance are primarily related, and leadership structures and corporate reporting are important factors that determine employee performance and there is a strong correlation. The study analyzed the connection between employee performance and independent variables (leadership structure and corporate reporting). The findings show that the variation in employee performance is explained by leadership structure, and corporate reporting, and recommends that management of any organization such as KEBS should develop an organizational culture that reports income and expenditure with transparency and ensures that annual reports are readily available. The study recommends that management should utilize an appropriate balance of leadership structure to enhance the likelihood of longerterm strategic effectiveness and employee performance.
\end{abstract}

Keywords: Leadership Structure, Corporate Reporting and Employee Performance 


\subsection{Introduction}

Good corporate governance practices play an important role in enhancing the efficiency and integrity of the corporate organization, as well as the financial markets in which organizations operate (Alareeni, 2018). According to Alareeni (2018), poor corporate governance weakens an organization's potential and this leads to organizational frauds or malpractice that affects performance and also reduces the morale of employees. Firms that are founded on best corporate governance practices are more profitable and competitive than organizations that have poor corporate governance. Such organizations attract investors, whose investments can finance organization growth (Liu, Lee, \& Tsai, 2019). According to OECD (2018), corporate governance defines the relationship between organization management or leadership, employees, board members, shareholders as well as the community.

According to Alareeni (2018), the best quality corporate governance practice is directly associated with a good organizational policy framework. Organizations that practice good corporate governance are not always affected by fraud, and other corporate scandals (Asogwa, Ofoegbu, \& Nnam, 2019). According to Asogwa, Ofoegbu, and Nnam (2019), good corporate governance improves the organization's corporate image as well as the reputation that attracts more investors and clients. Liu, Lee, and Tsai (2019) established that good corporate governance has a direct financial benefit to the organization and also boosts the competitive advantage of the organization. They further established that good corporate governance for investors is the key to decisionmaking on investments that ensures profits on their investments.

The components of corporate governance revolve around several basic principles that are classified as regulatory framework, accountability, and financial management, financial system, integrity in reporting (Malherbe \& Segal, 2020). According to Shleifer and Vishny (2018), there are four main principles of good corporate governance they are transparency, responsibility, fairness, and accountability. The principles determine and establish the necessary standards that provide legitimacy in the corporate sector. An organization that adopts these four principles is in a better position to perform better, attract investors and expand rapidly (Shleifer \& Vishny, 2018).

As cited by Kiratu (2016) corporate governance came into the limelight in the 1980s but it began in the 19th century in the United Kingdom as a result of the establishment of the joint-stock companies Act of 1844 that required organizations to be registered. By 1932 the process evolved to the modern corporation. In emerging economies, the prominence of corporate governance comes into light after corporate failures in developed countries such as in the United States of America with Enron and WorldCom while in Asia Golden Quadrilateral in India collapsed due to bad governance. The scandals in the US culminated in the formation of codes of conduct as a way of preventing corporate failures. The codes were developed in the United Kingdom by Cadbury report UK in 1992, in 1998 by OCED and Corporate Forum Principles of Japan, while in 2002 by Sarbanes-Oxley Sox. While in Africa it was developed by the Security Exchange Commission of Ghana for reinforcing ethics about transparency and accountability in public management (Karanja \& Wagana, 2017).

In East Africa, corporate governance has gained prominence as organizations moved towards market sustenance. In Kenya, the term corporate governance created a lot of interest after the events that took place in the US in the early nineteen-eighties despite the country developing and formulating new laws as well as adopting a progressive constitution in 2010. Corporate failures in Kenya have been a worrying trend, especially in the public sector. Few cases that include Mumias 
Sugar, Uchumi, Nakumatt, and Tuskys supermarkets, National Bank of Kenya, Kenya Airways, among many more are attributed to poor corporate governance (Siyad \& Sasaka, 2018).

The organization's anatomy is referred to as leadership structure that provides the foundations in which the organization functions (Choi, Chatfield, \& Chatfield, 2018). The leadership structure of the organization is considered to affect the behavior of employees in all aspects that include the process of decision-making (Nguyen, Ng, \& Yap, 2017). Choi, Chatfield, and Chatfield (2018) describe leadership structure as the model in which a firm operates as a workgroup and its processes. The leadership structure is typically described in different aspects. Yet according to Nguyen, Ng, and Yap (2017), leadership structure is the process of interaction within the organization. Scholars including Ghosal et al, (2017), refer to centralized leadership structure as the rigid hierarchical structure that authority is centered on an upper stratum. The centralized model of leadership structure is considered as autonomy that is influenced by discriminability in some decision-making (Chingara \& Heystek, 2019). According to Choi, Chatfield, and Chatfield (2018), an organization can achieve optimal performance, when its leadership structure matches the changes in its environment.

According to Labyntsev, et al. (2018), corporate reporting comprises official documented and promoted communication from organizations that is envisioned to offer an inclusive image of organization performance, and position to interested stakeholders. Therefore, corporate reporting comprises organization interim reports, annual reports, financial statements sustainability, and corporate social responsibility. Corporate reporting boils down to important components that are accountability and communication. Organizations are critically reevaluating how to communicate their performance and position of the firm as transparent as possible to shareholders (Labyntsev, Alekseeva, Evstafjeva, \& Osipova, 2018). Stakeholders are increasingly being sensible to the traditional financial reporting based on International Financial Reporting Standards (IFRS) which is sufficient enough for purpose of investing in the inadequate lack of information about the organization's future activities. Stakeholders are interested in the sustainable value creation activities of the firm apart from organization performance. Organization annual reports are seen as the cornerstone of corporate reporting and have been used over and over by governance experts. Good corporate reporting is a general indication of superior corporate governance. Good reports always address all the required relevant information and disclose through the measures taken that include strategic plans, corporate policy, initiatives to protect the environment, and organizations' prospects (Hoang, 2018). The recent influential reports by blue-chip organizations have suggested a variety of ways of reporting financial and non-financial information based on openness and transparency (Rashid, 2018).

Employee performance is defined as the level at which a worker fulfills his or her duties and executes assigned tasks and responsibilities (Flugum, Harper, \& Sun, 2020) while Armstrong and Taylor (2020) refer to employee performance as the efficiency, effectiveness, and quality of output provided by organization staff. Employee performance is affected by two types of forces (internal and external). The external forces that influence employee performance are competition, technology, and the working environment. The internal forces that influence employee performance are motivation, staff skills, training level, and staff ability (Kalia \& Bhardwaj, 2019). Therefore, organizational leadership needs to understand and address both internal and external forces that determine employee performance. The skilled employee poses in an organization keep the firm on a competitive edge. According to Armstrong and Taylor (2020), for employees to play their part effectively, they must be inspired and gratified. The organization's leadership needs to 
create a working atmosphere that is friendly and conducive. Also, organization policies should support employee performance. Therefore the success of an organization is much dependent on the performance of staff (Armstrong \& Taylor, 2020). The efficiency of employee performance can be determined by the regular ability and knowledge the staff acquire over time in the organization (Diamantidis \& Chatzoglou, 2019). Constructive employee perception regarding staff motivation and a conducive working environment are important factors that influence the interests of employees to accomplish organizational goals. For staff to remain relevant at the workplace their skills and abilities should enable them to carry out duties assigned by their supervisors (Dharma, 2018).

\subsection{Statement of the Problem}

According to Maravelaki, Doumpos, and Zopounidis (2017) corporate governance practices are widely recognized as the most essential element that strengthens the foundation for both organization and employee performance. Ethical dilemmas and lapses are the common root cause of several problems that corporate organizations face today, and the absence of good corporate governance practices is the underlying factor that affects well-performing organizations (Siyad \& Sasaka, 2018). Lack of sufficient corporate governance practices in government corporations and institutions has been evident in the collapse of several state corporations such as Kenya Meat Commission, Kenya Railways Corporation, Kenya Airways, Mumias Sugar Company, Webuye Pan Paper Mills, just to mention a few. State corporation's scandals lead to low employee morale, poor corporate image, low revenue and decrease in customer satisfaction which affects public faith in the organization. The overall Customer Satisfaction Survey (CSS) satisfaction index for KEBS went down from $64.09 \%$ for the financial year 2018/2019 to $58.9 \%$ for the year 2020/2021.

Several studies have been conducted on corporate governance and performance as Siyad and Sasaka (2018) conducted a study on corporate governance effects on the performance of telecommunication organizations and the study established that corporate practices enable the organization to concentrate on their core functions. The study focused on risk management, corporate reporting, leadership integrity, and managerial autonomy. The study has provided a contextual gap that needs to be examined. Laimaru (2018) examined the influence of governance principles on the performance of commercial state corporations in Kenya and the study established that the principle of accountability has a significant influence on performance. The study focused on the influence of accountability, transparency, fairness, and integrity, the study has provided an empirical and methodological gap that needs to be examined. This research focused on the influence of leadership structure, and corporate reporting. Therefore, the purpose of the study was to fill the knowledge gap by examining the influence of corporate governance practices on employee performance. And the study was answering the following questions; what is the relationship between corporate governance practices and employee performance?

\subsection{Objectives of the Study}

i. To examine the influence of leadership structure on employee performance at the Kenya Bureau of Standards

ii. To establish the influence of corporate reporting on employee performance at the Kenya Bureau of Standards 


\subsection{Scope of the Study}

The research was confined to Kenya Bureau of Standards Headquarters located in South C, Nairobi. This research was conducted between May 2021 and October 2021. The researcher targeted respondents in all levels of employment at KEBS that was providing the much-needed information on leadership structure, corporate reporting that was to determine the corporate governance practices and employee performance in state corporations a case study of Kenya Bureau of Standards. The researcher targets a sample size of 100 respondents.

\subsection{Literature Review}

\subsection{Theoretical Foundations}

This paper was anchored on stakeholders theory supported by Resource-based View theory.

\subsubsection{Stakeholders Theory}

The stakeholder concept appeared with the work of Freeman 1984. The theory is popular since scholars have established that the task of a corporate entity is influenced by the external environment, which is determined by institution accountability. The institutions or organizations are no longer identified as instruments of shareholders alone, but they are viewed within a societal context, hence the responsibility falls too in the social interest (Lange \& Bundy, 2018). About corporate governance the theory has two aspects; that is the abuse of the executive power model and the stakeholder model. According to Lange and Bundy (2018), Anglo-American corporate governance shows that excessive power is in the hands of management, and the managers may abuse these privileges to serve their interests at the expense of other stakeholders including society.

The misuse of executive power is always embedded in executive remuneration that has risen at a very fast rate, and this has formed a very weak link between performance, and compensation. Scholars that are pro this model do not believe that corporate governance reforms that include shareholder's, and non-executive involvement in decision making are suitable ways of monitoring mechanisms, instead, they prefer statutory changes in corporate governance in which hostile takeovers are not affected, and the appointment of executive officers is done on merit (Miles, 2017).

Stakeholder theory has faced numerous critics, and most of them have been based on the argument that the firm's success solely depends on the maximization of wealth. Jensen and Murphy (2004) have criticized the theory as it assumes that a single-valued objective and they suggest that the performance of an institution is not only measured by gains to its stakeholders but other issues such as information flow from senior managers to lower levels employees, working environment and interpersonal relations (Jensen \& Murphy, 2004). The theory is adopted by the study because the task of a corporate entity is influenced by the external environment, which is determined by institution accountability. Therefore, the theory was beneficial to the current study through the joint effect of leadership structure, and corporate reporting, and employee performance.

\subsubsection{Stewardship Theory}

This theory was developed in 1989 by Donaldson and Davis. The theory indicated that the steward maximizes and protects shareholders through employee performance. In this context, stewards are managers or executives that work for shareholders intending to make profits and protect their assets (Subramanian, 2018). Organizational success is fully dependent on the steward, and the employees take ownership of their responsibilities and work diligently with them. The theory 
adopts a different approach from agency theory; in that organization serves a big social purpose compared to maximizing the wealth of the shareholders. It holds that corporations and institutions are social entities that determine stakeholders' welfare that interact with the organization as well as the organizational objectives (Keay, 2017). According to Surbramanian (2018), stakeholders have moral as well as legal rights and are instrumental to corporate success. Therefore, corporate managers have to consider stakeholders' claims when conducting business as well as making decisions towards stakeholders.

Donaldson and Preston, (1995) while defining stakeholder theory indicated that the organization is a system of stakeholders that operates within a large system that offers necessary market, and legal infrastructure for the organization's activities. The goals and objectives of the organization are creating wealth or adding value for its stakeholders. The view is echoed by Blair (1995) who described the goal of directors and organization management as to create and maximize wealth for the organization. Organizations adopt approaches that are either proactive or reactive when incorporating stakeholders in decision-making. An organization opts for a reactive approach when it does not incorporate its stakeholders into corporate decision making thus resulting in a misalignment of stakeholders' demands and organizational goals (Keay, 2017). Corporate scandals such as those of Worldcom, and Enron to the failure of incorporating stakeholders' concerns in decision making. According to Adams (2010), the theory remains the foundation for legislation, and regulation in the corporate decision-making process and establishes necessary governance structures. The study adopted this theory to analyze how corporate reporting, management, and leadership structure put in place, empowering, and facilitating empowerment structures rather than monitoring, and controls, as suggested by other theories that interfere rather with steward motivation of ensuring the agent (management) with stakeholder's interest, are aligned to promote the effectiveness of agent in pursuit of the improved employee, and organization performance in the long term.

\subsection{Empirical Studies}

\subsubsection{Leadership Structure and Employee Performance}

Asogwa, Ofoegbu, and Nnam (2019) investigated the effects of corporate governance leadership models and attributes on organization earnings using Nigerian listed firms. The study adopted a descriptive research survey that targeted 37 firms listed in the Nigerian Stock exchange between 2014-2018 using stratified random sampling. The study also adopted an ex-post facto design that used regression to analyze data. The study findings showed that unitary corporate leadership and dual board leadership model has a significant influence on improving organization earnings, the study also established that organization earnings grow in organizations where the CEO and chairs of the board qualify for financial management, and the quality of earning greatly improves significantly when leadership structure has a good mix of legal skills and financial expertise in the board composition, thus capital market places a premium on good leadership attribute mix (Asogwa, Ofoegbu, \& Nnam, 2019). This study provides a contextual and empirical gap that concentrated on non-financial firms in Nigeria that cannot be generalized as its context is specific. Bentley, Pugalis, and Shutt (2017) examined the leadership and system of governance in the case of the constraints on the scope for leadership structure of placed-based development in subnational regions. The study adopted a descriptive research design, that targeted a study population of 3739 employees. Random stratified sampling was used to select 463 respondents to participate in the research. The study used structural equation modeling to establish if there is a relationship 
between leadership structure, and governance systems, and employee performance. The study established that deploying dual concepts of acceptability, and permissibility provides an innovative analytical device for decrypting corporate leadership, and also the study established that control mechanisms characteristics of governance are shaped by leadership autonomy (Bentley, Pugalis, \& Shutt, 2017). The study provides an empirical gap and context that needs to be filled.

Feng, Hassan, and Elamer, (2020) investigated corporate governance, ownership, capital, and leadership structure regarding Chinese Real estate firms listed on the stock exchange. The study intended to contribute to the existing literature on ownership, capital, and leadership structure. The study used panel data comprised of 595 organizational from a comprehensive, and unique data set of 119 real estate firms in china that were listed in the stock exchange between 2014-2018. The study data were analyzed using a fixed, and random effect regression analysis to establish and examine the study hypothesis. The study established that leadership structure, the board size, ownership concentration, and organization size have a positive influence on capital structure, and also established that government ownership and profitability have an inverse influence on both leadership and capital structure (Feng, Hassan, \& Elamer, 2020). The study has provided a methodological and contextual gap that this study will try to fill.

\subsubsection{Corporate Reporting and Employee Performance}

A study by Okumus, Kuyucak-Sengur, Koseoglu, and Sengur (2020) examined what companies report for their CSR practices on their website. The study intended to examine how Turkish airline reports CSR efforts on its website. The study adopted a content analysis that was carried out using policies, reports, publications, and other available documents on CSR for the period ending 2017. The study established that Turkish Airlines has documented several reports highlighting their CRS activities in annual reports, and organization policy documents, the study also established that the environmental dimension is the most area that the Airline has placed more focus on (Okumus, Kuyucak-Sengur, Koseoglu, \& Sengur, 2020). The study has provided a methodological gap and contextual gap in a model and data-driven analysis that needs to be filled in a local perspective.

Zúñiga, Pincheira, Walker, and Turner, (2020) examined the effect of integrated corporate reporting on quality on market liquidity, and analyst forecast error. The study adopted the use of the Sustainability Disclosure Transparency Index (SDTI) for integrated corporate reporting and analysis. That study targeted 324 organizations and sampled 170 organizations listed in the Johannesburg Stock exchange between 2013-2015. Data were analyzed using the integrated reporting quality that was developed using Integrated Reporting and Assurance Services (IRAS), and ordinary least squares regression. The study also used Variance Inflation Factor (VIF), and its tolerance to test the severity of multi-collinearity. The study findings showed that the quality of corporate reporting is associated with lower earnings forecast error, and the errors are higher for organizations with volatile returns; the study also established that integrated corporate reporting is positively associated with market liquidity (Zúñiga, Pincheira, Walker, \& Turner, 2020). The study results cannot be generalized in other jurisdictions hence the study has provided empirical and contextual gaps that need to be filled.

A study by Gnanaweera, Kunori, and Ntim (2018) examined corporate sustainability reporting that links corporate disclosure information and performance indicators. The study targeted 85 Japanese firms listed in Tokyo Stoke Exchange between 2008-2014. The study adopted a content analysis and regression analysis to examined the main study objective, from the content analysis finding of the study established that listed firms in Tokyo Stoke Exchange level of discloser on the environmental, economical, and social information varies from one firm to another, the study also 
established due to week positive significant linkage among corporate sustainability disclosure guidelines rate, water consumption, environmental conversation effort, and firm size. However, to be consistent with social values, the firms ensure that the guideline, and accuracy in the disclosure of information on corporate sustainability reporting (Gnanaweera, Kunori, \& Ntim, 2018). The study has provided empirical and contextual gaps that need to be examined in a local context.

\subsection{Conceptual framework}

The study was guided by a conceptual framework that presents and defines the viewpoints that attempt to explain the research problem under the study.

Independent Variables

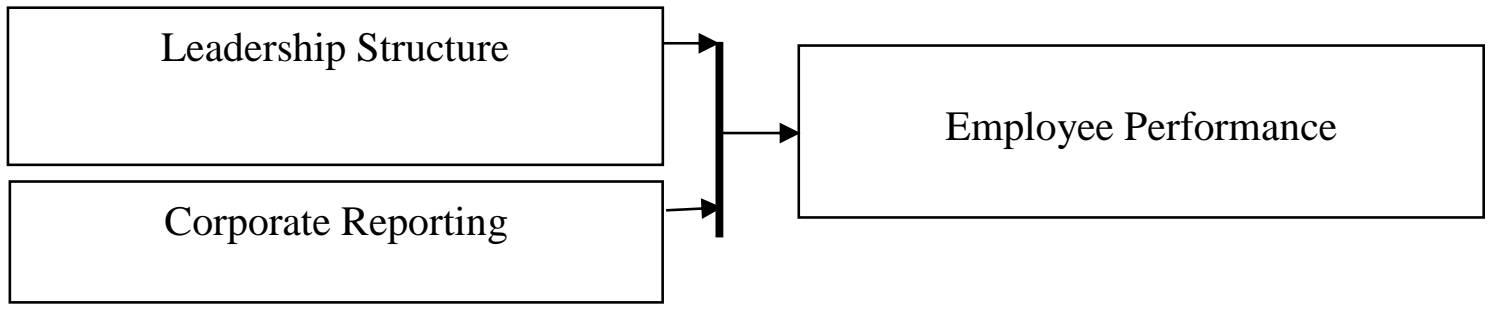

Figure 1 Conceptual Framework

\subsection{Research Methodology}

\subsection{Research Design}

A descriptive research design was used in the study. The descriptive research design involved describing the behavior without influencing it in any way. The design is normally used before using quantitative research designs to identify valuable indications as to the variables that are to be tested (Bordens \& Abbott, 2017). The research study adopted a quantitative research design since the primary goal is often to have a better understanding of the research study, the results obtained by the study should be in a position to be used in generalizing findings in an array of organizations.

\subsection{Target Population}

Kothari and Garg (2015) and Cooper and Schindler (2016) define target population as the total collection of elements which one wishes to generalize the research conclusion. Researcher targets all employees of KEBS that included senior managers, supervisors, and ordinary staff as the study target population as presented below

\subsection{Sample and Sampling Technique}

Kothari and Garg (2015) define a sample as the section of the population used in representing characteristics of the population. Cooper and Schindler (2018) observed that the study sample size should be random to avoid biases. As recommended by Saunders, Lewis, and Thornhill (2018) $10 \%$ of the target population is deemed reasonable to be used as the sample size. The study adopted $10 \%$ as per recommendation that gives a sample size of 100 respondents that was used in this study. 


\subsection{Data Collection Instruments}

Kothari and Garg (2015) explain that several tools exist for data collection, the tools include interviews, questionnaires, focus groups, observations. A research instrument that is suitable to measure respondent's perception is required and in this study, the author prefers to use questionnaires. The researcher used questionnaires because it makes it possible and easy for correlation, descriptive, and inferential statistical analysis as echoed by Saunders, Lewis, and Thornhill (2018). These questions also aided in enriching the qualitative methodology effectively. The questionnaire further provided anonymity as most respondents always don't prefer their identity revealed. Primary data was collected using questionnaires while secondary data used in the literature review was collected from documented sources such as journals, monographs, articles, books, and company reports.

\subsection{Data Analysis and Presentation}

Kothari and Garg (2015) Define data analysis as the process in which raw data collected from research data collection tools are sorted and organized so as to extract useful information. The study will generate quantitative data. The qualitative data was analyzed using simple statistics and SPSS. The raw data gathered from the field was coded before the generalization of the findings is made. The results were analyzed using descriptive statistics and presentations was in tables, and figures. Inferential statistics was used to show the connection that exists between the study variables. The study used the Pearson correlation matrix was used. Pearson correlation helped in predicting and describing the association between the variables in terms of magnitude and direction. The correlation test at a 5\% level of significance with a 2-tailed test was conducted.

Analysis of variance (ANOVA) was adopted to disclose the complete model significance. The calculated $\mathrm{f}$ statistic was compared with the tabulated $\mathrm{f}$ statistic. A critical p-value of 0.05 was used to determine whether the overall model was significant or not. A multiple linear regression model was used to test the significance of the influence of the independent variables on the dependent variable. To estimate the model of the composite index of the employee performance measure, $\alpha$ is a regression constant or intercept, $\beta 1-4$ is the regression coefficient. EE represents the composite score of employee performance as the independent variable. JRA represents the other variables composite index. The variables are represented by IF which is the composite score of leadership structure, corporate reporting, board composition, and ethical code of conduct. $\varepsilon$ is the random error term that accounts for the viability of the corporate governance practices that cannot be explained by the linear effect of the predictor variables. The multiple linear regression models are as follows

$\mathrm{Y}=\beta 0+\beta 1 \mathrm{X} 1+\beta 2 \mathrm{X} 2+\beta 3 \mathrm{X} 3+\beta 4 \mathrm{X} 4+\varepsilon$

Where:

$\mathrm{Y}=$ Employee Performance

$(\mathrm{Bi} ; \mathrm{i}=1,2,3,4)=$ various coefficients for the independent variables

$\mathrm{Xi}$ for;

$\mathrm{X} 1=$ Leadership structure

$\mathrm{X} 2=$ Corporate reporting

X3= Board composition 
$\mathrm{X} 4=$ Ethical code of conduct

\subsection{Research Findings and Discussion}

\subsection{Response Rate}

The results obtained show that a total of 91 respondents filled and emailed back the questionnaires that represented $91 \%$ response rate while $9 \%$ of the respondents failed to email their responses back, and some of the emailed questionnaires were not fully filed, therefore the study did not include them in the final analysis. The response rate was excellent. Kothari and Grag (2015) explain that any research study that obtains a response rate of fifty percent is adequate for analysis, while any response that is sixty percent is rated as good, and any responses above seventy percent are deemed to be excellent. This implies that the research response rate was excellent.

Table 1: Return Rate

\begin{tabular}{lll}
\hline Category & Frequency & Percentage \\
\hline Responses & 91 & 91 \\
Non-Responses & 9 & 9 \\
Total & $\mathbf{1 0 0}$ & $\mathbf{1 0 0}$ \\
\hline
\end{tabular}

\subsection{Demographic Information}

Table 2: Respondents Gender

\begin{tabular}{lll}
\hline Category & Frequency & Percentage \\
\hline Male & 54 & 59 \\
Female & 37 & 41 \\
Total & $\mathbf{9 1}$ & $\mathbf{1 0 0}$ \\
\hline
\end{tabular}

Most employees who participated in the research were males representing 59\% of the respondents and $41 \%$ were female as shown in Table 2 . This implies that the gender representations of the respondents were not fairly balanced in the study and contributions towards the study findings cannot be associated with any single-gender despite male respondents being more than their female counterparts. Kothari and Grag (2015) indicate that respondent's gender is one of the most important characteristics in understanding their views about particular issues. By and large, gender shows the level of commitment, technical skills, and nature of energy required to carry out specific functions.

\subsection{Descriptive Analysis}




\subsubsection{Leadership structure and Employee Performance in State Corporations}

Table 3: Model Summary of leadership structure

Model Summary of Leadership structure

\begin{tabular}{|c|c|c|c|c|c|c|c|c|c|}
\hline \multirow[b]{2}{*}{ Model } & \multirow[b]{2}{*}{$\mathbf{R}$} & \multirow[b]{2}{*}{$\begin{array}{c}\mathbf{R} \\
\text { Square }\end{array}$} & \multirow[b]{2}{*}{$\begin{array}{l}\text { Adjusted } \\
\text { R Square }\end{array}$} & \multirow{2}{*}{$\begin{array}{l}\text { Std. The } \\
\text { error of the } \\
\text { Estimate }\end{array}$} & \multicolumn{5}{|c|}{ Change Statistics } \\
\hline & & & & & $\begin{array}{l}\text { R Square } \\
\text { Change }\end{array}$ & $\begin{array}{c}\text { F } \\
\text { Change }\end{array}$ & df1 & df2 & $\begin{array}{c}\text { Sig. F } \\
\text { Change }\end{array}$ \\
\hline 1 & $0.548 \mathrm{a}$ & 0.151 & 0.142 & 0.724 & 0.151 & 15.872 & 1 & 89 & 0.000 \\
\hline
\end{tabular}

a. Predictors: (Constant), Leadership structure

Regression analysis was done with employee performance as the dependent variable and leadership structure as the predictor factor. The regression analysis revealed a relationship $\mathrm{R}=$ 0.548 which showed a strong correlation and revealed that leadership structure and employee performance are primarily related, the study established a strong positive relationship between the variables $(\mathrm{r}=0.548, \mathrm{p}=0.000)$ as shown in Table 3. Consequently, proliferation in leadership structure will improve employee performance and the variations in employee performance can be explained by other factors.

Table 4: ANOVA ${ }^{\text {a }}$ Results for leadership structure

\begin{tabular}{cccccc}
\hline \multicolumn{5}{c}{ ANOVA $^{\mathbf{a}}$} \\
\hline $\mathbf{1}$ & Sum of Squares & df & Mean Square & F & Sig. \\
\hline Regression & 8.329 & 1 & 8.329 & 15.872 & $0.000 \mathrm{~b}$ \\
Residual & 46.704 & 90 & 0.525 & & \\
Total & 55.033 & 91 & & &
\end{tabular}

a. Dependent Variable: Employee performance

b. Predictors: (Constant), Leadership structure

The values of $F=15.872$ show that leadership structure statistically and significantly affects employee performance which means the regression model is a good fit of the data and that leadership structure significantly influences the employee performance at KEBS. The level of significance is 0.000 which is less than 0.05 hence the regression model significantly predicts the dependent variable. The results were enumerated as seen in Table 4.

Table 5: Regression Coefficients ${ }^{\mathbf{a}}$ for leadership structure

\begin{tabular}{|c|c|c|c|c|c|}
\hline \multirow[b]{3}{*}{$\begin{array}{c}\text { Model } \\
1\end{array}$} & \multicolumn{3}{|c|}{ Coefficients $^{\mathbf{a}}$} & \multirow[b]{3}{*}{$\mathbf{t}$} & \multirow[b]{3}{*}{ Sig. } \\
\hline & \multicolumn{2}{|c|}{$\begin{array}{l}\text { Unstandardized } \\
\text { Coefficients }\end{array}$} & \multirow{2}{*}{$\begin{array}{c}\begin{array}{c}\text { Standardized } \\
\text { Coefficients }\end{array} \\
\text { Beta } \\
\end{array}$} & & \\
\hline & B & $\begin{array}{c}\text { Std. } \\
\text { Error }\end{array}$ & & & \\
\hline (Constant) & 2.144 & 0.420 & & 5.100 & 0.000 \\
\hline
\end{tabular}




\begin{tabular}{cccccc}
\hline Leadership structure & 0.403 & 0.101 & 0.389 & 3.984 & 0.000 \\
a. Dependent Variable: Employee performance & & & & \\
\hline
\end{tabular}

An ANOVA analysis was conducted between leadership structure and employee performance at a 95\% confidence level. The F critical was 15.872 and the P-value was $(0.000)$ therefore the significance of the results as shown in table 3 the regression equation developed was $\mathrm{Y}=\beta 0+\beta 1 \mathrm{X} 1+\varepsilon ; \mathrm{Y}=2.144+0.403 \mathrm{X} 1+0.420$

\subsubsection{Corporate Reporting and Employee Performance in State Corporations}

Table 6: Model Summary of Corporate reporting Model Summary

Std.

Error of

R Adjusted

Model $R$ Square R Square Estimate
Change Statistics

$\begin{array}{ccccc}\text { R Square } & \text { F } & \text { Sig. F } \\ \text { Change } & \text { Change } & \text { df1 } & \text { df2 } & \text { Change }\end{array}$

$\begin{array}{llllllllll}1 & 0.302 \mathrm{a} & 0.091 & 0.081 & 0.750 & 0.091 & 8.957 & 1 & 89 & 0.004\end{array}$

a. Predictors: (Constant), Corporate reporting

Regression analysis was carried out with employee performance as the dependent variable and corporate reporting as the predictor factor. The regression analysis revealed a relationship $\mathrm{R}=$ 0.302 which showed a moderate correlation and revealed that corporate reporting and employee performance are significantly connected, the study established a strong positive relationship between the variables $(\mathrm{r}=0.302, \mathrm{p}=0.004)$ as shown in table 4 . And the variations in employee performance can be explained by other study variables such as leadership structure, and other factors within the organization.

Table 7: ANOVA ${ }^{\text {a }}$ Results for Corporate Reporting

\begin{tabular}{cccccc}
\hline \multicolumn{7}{c}{ ANOVA $^{\mathbf{a}}$} \\
Model & $\begin{array}{c}\text { Sum of } \\
\text { Squares }\end{array}$ & df & Mean Square & F & Sig. \\
\hline Regression & 5.032 & 1 & 5.032 & 8.957 & $0.002 \mathrm{~b}$ \\
Residual & 50.001 & 89 & 0.562 & & \\
Total & $\mathbf{5 5 . 0 3 3}$ & $\mathbf{9 0}$ & & & \\
a. Dependent Variable: Employee performance & & & \\
b. Predictors: (Constant), Corporate reporting &
\end{tabular}

The values of $\mathrm{F}=8.957$ show that corporate reporting significantly affects employee performance which means the regression model is a good fit of the data and that corporate reporting significantly influences the employee performance at KEBS. The level of significance is 0.002 which is less than 0.05 hence the regression model significantly predicts the dependent variable. 
The results were enumerated as seen in Table 7.

Table 8: Regression Coefficients ${ }^{\mathrm{a}}$ for Corporate Reporting

\begin{tabular}{|c|c|c|c|c|c|}
\hline \multirow[b]{3}{*}{ Model } & \multicolumn{2}{|c|}{ Coefficients $^{\mathrm{a}}$} & \multirow{3}{*}{$\begin{array}{c}\text { Standardize } \\
\text { d } \\
\text { Coefficients } \\
\text { Beta } \\
\end{array}$} & \multirow[b]{3}{*}{$\mathbf{t}$} & \multirow[b]{3}{*}{ Sig. } \\
\hline & \multicolumn{2}{|c|}{$\begin{array}{l}\text { Unstandardized } \\
\text { Coefficients }\end{array}$} & & & \\
\hline & B & Std. Error & & & \\
\hline (Constant) & 2.760 & 0.353 & & 7.808 & 0.000 \\
\hline Corporate reporting & 0.270 & 0.090 & 0.302 & 2.993 & 0.002 \\
\hline
\end{tabular}

An ANOVA analysis was conducted between corporate reporting and employee performance at a 95\% confidence level. The F critical was 15.872 and the P-value was (0.002) therefore the significance of the results as shown in table 6 the regression equation developed was $\mathrm{Y}=\beta 0+\beta 2 \mathrm{X} 2+\varepsilon ; \mathrm{Y}=2.760+0.270 \mathrm{X} 2+0.353$

\subsubsection{Employee Performance and Employee Performance in State Corporations}

Regression Analysis of Employee Performance

Table 9: Model summary Employee Performance

\begin{tabular}{|c|c|c|c|c|c|c|c|c|c|}
\hline \multirow[b]{2}{*}{ Model } & \multirow[b]{2}{*}{$\mathbf{R}$} & \multirow[b]{2}{*}{$\begin{array}{c}\mathbf{R} \\
\text { Square }\end{array}$} & \multirow[b]{2}{*}{$\begin{array}{c}\text { Adjusted } \\
\text { R } \\
\text { Square }\end{array}$} & \multirow[b]{2}{*}{$\begin{array}{c}\text { Std. } \\
\text { Error } \\
\text { of the } \\
\text { estimate }\end{array}$} & \multicolumn{5}{|c|}{ Change Statistics } \\
\hline & & & & & $\begin{array}{c}\text { R } \\
\text { Square } \\
\text { Change }\end{array}$ & $\begin{array}{c}\text { F } \\
\text { Change }\end{array}$ & df1 & df2 & Sig. F \\
\hline 1 & $.780^{\mathrm{a}}$ & .611 & .594 & .45801 & .611 & 46.601 & 3 & 88 & .000 \\
\hline
\end{tabular}

The study analyzed the connection between employee performance and independent variables (leadership structure, and corporate reporting) the findings show that the $\mathrm{R}^{2}$ value was 0.611 therefore, $61.1 \%$ of the variation in employee performance is explained by leadership structure, corporate reporting shown in table 9.

Table 10: ANOVA of Employee Performance

\begin{tabular}{ccccccc}
\hline Model & \multicolumn{7}{c}{ ANOVA $^{\mathbf{a}}$} & & & & \\
\hline & & $\begin{array}{c}\text { Sam of } \\
\text { Squares }\end{array}$ & df & $\begin{array}{c}\text { Mean } \\
\text { square }\end{array}$ & f & Sig. \\
& Regression & 26.813 & 4 & 8.931 & 46.601 & $.000^{\mathrm{b}}$ \\
& & & .310 & & \\
& Residual & 16.889 & 86 & & & \\
Total & 47.602 & 90 & & & \\
\hline
\end{tabular}


a. Dependable Variable is Employee performance

b. Leadership structure, corporate reporting

The values of 46.601 show that employee performance is influenced by independent variables (leadership structure, and corporate reporting) which means the regression model is a good fit for the data and that employee performance at KEBS is significantly influenced by leadership structure and corporate reporting. The level of significance is 0.000 which is less than 0.05 hence the regression model significantly predicts the dependent variable. The results were tabulated in Table 10 .

Table 11: Regression Coefficients ${ }^{\text {a }}$ for Employee Performance

\begin{tabular}{ccccccc}
\hline \multicolumn{1}{c}{ Coefficients } \\
\hline & \multicolumn{2}{c}{ Unstandardized } & \multicolumn{2}{c}{$\begin{array}{c}\text { Standardized } \\
\text { Coefficients }\end{array}$} & & \\
& & Coefficients & & \\
& & Std. error & Beta & t & Sig \\
\hline 1 & Constant & 0.844 & 0.288 & & 2.578 & 0.000 \\
& Leadership structure & 0.403 & 0.101 & 0.389 & 3.984 & 0.000 \\
& Corporate reporting & 0.270 & 0.090 & 0.302 & 2.993 & 0.004 \\
\hline
\end{tabular}

The regression analysis is shown in table 11 established that all factors put into consideration and leadership structure, corporate reporting, and other factors are held constant employee performance will increase by 0.844 The multiple linear regression models as established by the study findings is laid as $\mathrm{Y}=\beta 0+\beta 1 \mathrm{X} 1+\beta 2 \mathrm{X} 2+\mathrm{e}$

Employee performance $=0.844+0.403 \mathrm{X} 1+0.270 \mathrm{X} 2+0.288$

\subsection{Summary, Conclusion and Recommendation}

\subsection{Summary of the Research Findings}

The study aimed to establish the effects of leadership structure on employee performance at KEBS. The study variable was assessed by requiring the respondents to use a five-point Likert scale and the researcher sought to examine how leadership structure determines employee performance. The findings show that leadership structure and employee performance are primarily related, and leadership structures are an important factor that determines employee performance of the organization. Regression analysis was done with employee performance as the dependent variable and leadership structure as the predictor factor. The regression analysis revealed a relationship $\mathrm{R}$ $=0.548$ which showed a strong correlation and revealed that leadership structure and employee performance are primarily related, the study established a strong positive relationship between the variables $(\mathrm{r}=0.548, \mathrm{p}=0.000)$. Consequently, proliferation in leadership structure will improve employee performance and the variations in employee performance can be explained by other factors. An ANOVA analysis was conducted between leadership structure and employee performance at a 95\% confidence level. The F critical was 15.872 and the P-value was (0.000). The values of $F=15.872$ show that leadership structure statistically and significantly affects employee performance which means the regression model is a good fit of the data and that leadership structure significantly influences the employee performance at KEBS. The level of 
significance is 0.000 which is less than 0.05 hence the regression model significantly predicts the dependent variable.

The findings are similar to other studies such as Asogwa, Ofoegbu, and Nnam (2019) findings showed that unitary corporate leadership and dual board leadership model has a significant influence on improving organization earnings, the study also established that organization earnings grow in organizations where the CEO and chairs of the board qualify for financial management, and the quality of earning greatly improves significantly when leadership structure has a good mix of legal skills and financial expertise in the board composition, thus capital market places a premium on good leadership attribute mix. Bentley, Pugalis, and Shutt (2017) established that deploying dual concepts of acceptability, and permissibility provides an innovative analytical device for decrypting corporate leadership, and also the study established that control mechanisms characteristics of governance are shaped by leadership autonomy. Feng, Hassan, and Elamer, (2020) established that leadership structure, the board size, ownership concentration, and organization size have a positive influence on capital structure, and also established that government ownership and profitability have an inverse influence on both leadership and capital structure.

On the second objective the study findings clearly show that corporate reporting influences employee performance. Regression analysis was carried out with employee performance as the dependent variable and corporate reporting as the predictor factor. The regression analysis revealed a relationship $\mathrm{R}=0.302$ which showed a moderate correlation and revealed that corporate reporting and employee performance are significantly connected, the study established a strong positive relationship between the variables $(\mathrm{r}=0.302, \mathrm{p}=0.004)$, and the variations in employee performance can be explained by other study variables such as leadership structure, board composition, ethical code of conduct and other factors within the organization. An ANOVA analysis was conducted between corporate reporting and employee performance at a $95 \%$ confidence level. The F critical was 15.872 and the P-value was (0.002) therefore the significance. The values of $\mathrm{F}=8.957$ show that corporate reporting significantly affects employee performance which means the regression model is a good fit of the data and that corporate reporting significantly influences the employee performance at KEBS. The level of significance is 0.002 which is less than 0.05 hence the regression model significantly predicts the dependent variable.

The study findings are similar to findings of other studies such as Okumus, Kuyucak-Sengur, Koseoglu, and Sengur (2020) established that Turkish Airlines has documented several reports highlighting their CRS activities in annual reports, and organization policy documents, the study also established that the environmental dimension is the most area that the Airline has placed more focus on. Zúñiga, Pincheira, Walker, and Turner, (2020) examined the effect of integrated corporate reporting on quality on market liquidity, and analyst forecast error. The study findings showed that the quality of corporate reporting is associated with lower earnings forecast error, and the errors are higher for organizations with volatile returns; the study also established that integrated corporate reporting is positively associated with market liquidity. Gnanaweera, Kunori, and Ntim (2018) established that listed firms in Tokyo Stoke Exchange level of discloser on the environmental, economical, and social information varies from one firm to another, the study also established due to week positive significant linkage among corporate sustainability disclosure guidelines rate, water consumption, environmental conversation effort, and firm size. However, to be consistent with social values, the firms ensure that the guideline, and accuracy in the disclosure of information on corporate sustainability reporting. 


\subsection{Conclusion}

The study established that leadership structure and employee performance are primarily related and have a strong correlation therefore leadership structure is an important factor that determines employee performance. The study concludes that leadership structure statistically and significantly affects employee performance.

The results also showed that corporate reporting influences employee performance. Regression analysis shows a moderate correlation and revealed that corporate reporting and employee performance are significantly connected. The study concludes that there is a positive relationship between corporate reporting and employee performance in an organization.

\subsection{Recommendations}

The researcher recommends that KEBS management should create a clear chain of command that indicates the reporting structure. Titles and positions in all departments should be in line with KEBS organizational structure and Staff Establishment. KEBS management should share the organization structure with all employees including new employees during the orientation program. Management of KEBS should develop and formulate guidelines, governing structures, and strategic plans for the effective implementation of organizational goals and objectives.

Senior management at KEBS needs to utilize an appropriate balance of leadership structure to enhance the likelihood of longer-term strategic effectiveness and employee performance. Corporate reporting is an integral part of organizational success and therefore the study recommends that management of any organization such as KEBS should develop an organizational culture that reports income and expenditure with transparency and ensures that annual reports are readily available.

\section{References}

Alareeni, B. (2018). Does corporate governance influence earnings management in listed companies in Bahrain Bourse? Journal of Asia Business Studies, Vol. 12 (4), 551-570.

Asogwa, C. I., Ofoegbu, G. N., \& Nnam, J. I. (2019). Effect of corporate governance board leadership models and attributes on earnings quality of quoted Nigerian companies. Cogent Business \& Management vol.6(1), 1-24.

Bentley, G., Pugalis, L., \& Shutt, J. (2017). Leadership and systems of governance: the constraints on the scope for leadership of place-based development in sub-national territories. Regional Studies vol. 27(2), 194-209.

Bickman, L., \& Rog, D. (2018). Applied research design: A practical approach. Thousand Oaks: Sage Publishers.

Bordens, K., \& Abbott, B. B. (2017). Research Design and Methods: A Process Approach 10th Edition. London: McGraw-Hill Education.

Chingara, R., \& Heystek, J. (2019). Leadership as the agency in the context of structure". International Journal of Educational Management, Vol. 33(7), 1596-1609.

Choi, D., Chatfield, H., \& Chatfield, R. (2018). Agency or stewardship? The impact of leadership structure on the debt financing of lodging firms (leadership structure on debt financing. 
International Journal of Contemporary Hospitality Management, Vol. 30 No. 3, pp. , 13521373.

Cooper, D., \& Schindler, P. S. (2018). Business Research Methods. New Delhi: McGraw Hill.

Creswell, J. W., \& Creswell, J. D. (2018). Research Design: Qualitative, Quantitative, and Mixed Methods Approaches. 5th edition. . Thousand Oaks, CA: Sage.

Dharma, Y. (2018). The Effect of Work Motivation on the Employee Performance with Organization Citizenship Behavior as Intervening Variable at Bank Aceh Syariah", Proceedings of MICoMS 2017 ). Emerald Reach Proceedings Series, Vol. 1, 7-12.

Diamantidis, A., \& Chatzoglou, P. (2019). Factors affecting employee performance: an empirical approach. International Journal of Productivity and Performance Management, Vol. 68(1), 171-193.

Dunaetz, D. A. (2020). Research Methods and Survey Applications: Outlines and Activities. New York: Martel Press.

Feng, Y., Hassan, A., \& Elamer, A. A. (2020). Corporate governance, ownership structure and capital structure: evidence from Chinese real estate listed companies. International Journal of Accounting \& Information Management, Vol. 28(4), 759-783.

Gnanaweera, K., Kunori, N., \& Ntim, C. G. (2018). Corporate sustainability reporting: Linkage of corporate disclosure information and performance indicators. Cogent Business \& Management vo.5(1), 1-21.

Hoang, T. (2018). The Role of the Integrated Reporting in Raising Awareness of Environmental, Social and Corporate Governance (ESG) Performance", Stakeholders, Governance and Responsibility. Developments in Corporate Governance and Responsibility, Vol. 14, 4769.

Keay, A. (2017). Stewardship theory: is board accountability necessary? International Journal of Law and Management, Vol. 59(6), 1292-1314.

Kothari, C. R., \& Garg, T. (2015). Research Methodology. New Delhi: New Age International.

Labyntsev, N., Alekseeva, I., Evstafjeva, E., \& Osipova, R. (2018). Corporate Reporting Formation at Commercial Organizations", Grima, S. and Thalassinos, E. (Ed.) Contemporary Issues in Business and Financial Management in Eastern Europe. Contemporary Studies in Economic and Financial Analysis, Vol. 100, 100-130.

Liu, C.-Y., Lee, C.-Y., \& Tsai, H.-J. (2019). Corporate governance and food firms' unethical production practices? British Food Journal, Vol. 120 No. 10, 2222-2235.

Malherbe, S., \& Segal, N. (2020). Corporate Governance in South Africa. Paris: OECD Development Centre.

Miles, S. (2017). Stakeholder Theory Classification, Definitions, and Essential Contestability", Stakeholder Management. Business and Society 360, Vol. 1, 21-47. 
Nguyen, D., Ng, D., \& Yap, P. (2017). Instructional leadership structure in Singapore: a coexistence of hierarchy and heterarchy. Journal of Educational Administration, Vol. 55(2), 147-167.

Obermann, J., Velte, P., Gerwanski, J., \& Kordsachia, O. (2020). Mutualistic symbiosis? Combining theories of agency and stewardship through behavioral characteristics. Management Research Review, Vol. 43(8), 989-1011.

OECD. (2018). OECD Principles of Corporate Governance. Paris: OECD.

Okumus, F., Kuyucak-Sengur, F., Koseoglu, M., \& Sengur, Y. (2020). What do companies report for their corporate social responsibility practices on their corporate websites? Evidence from a global airline company. Journal of Hospitality and Tourism Technology, Vol. 11(3), $385-405$.

Rashid, A. (2018). The influence of corporate governance practices on corporate social responsibility reporting. Social Responsibility Journal, Vol. 14 (1), 20-39.

Rouf, M., \& Hossan, M. (2020). The effects of board size and board composition on CSR disclosure: a study of banking sectors in Bangladesh. International Journal of Ethics and Systems, Vol. 37(1), 105-100.

Saunders, M., Lewis, P., \& Thornhill, A. (2018). Research Methods for Business Students. London: Financial Times.

Shleifer, A., \& Vishny, R. (2018). A Survey of Corporate Governance. Journal of Finance, Vol. $52,737-783$.

Siyad, B. M., \& Sasaka, P. (2018). The effect of corporate governance on the performance of Hormud Telecommunication Company. The Strategic Journal of Business \& Change Management vol. 5(1), 849 - 871.

Subramanian, S. (2018). Stewardship Theory of Corporate Governance and Value System. Indian Journal of Corporate Governance vol. 11(1), 88-102.

Thornhill, A., Lewis, P., \& Saunders, M. (2019). Research Methods For Business Students. London: Pearson Education.

Zúñiga, F., Pincheira, R., Walker, J., \& Turner, M. (2020). The effect of integrated corporate reporting quality on market liquidity and analyst forecast error. Accounting Research Journal, Vol. 33 No. (4/5), 635-650. 